\title{
Bioleaching of heavy metals from printed circuit board (PCB) by Streptomyces albidoflavus TN10 isolated from insect nest
}

\author{
Dhanalashmi Kaliyaraj ', Menaka Rajendran' ${ }^{1}$ Vignesh Angamuthu², Annam Renita Antony ${ }^{1}$, Manigundan Kaari², \\ Shanmugasundaram Thangavel ${ }^{3}$, Gopikrishnan Venugopal ${ }^{2}$, Jerrine Joseph ${ }^{2}$ and Radhakrishnan Manikkam ${ }^{2^{*}}$ (D)
}

\begin{abstract}
Background: E-waste management is extremely difficult to exercise owing to its complexity and hazardous nature. Printed circuit boards (PCBs) are the core components of electrical and electronic equipment, which generally consist of polymers, ceramics, and heavy metals.

Results: The present study has been attempted for removal of heavy metals from printed circuit board by metalresistant actinobacterium Streptomyces albidoflavus TN10 isolated from the termite nest. This bacterium was found to recover different heavy metals (Al 66\%, Ca 74\%, Cu 68\%, Cd 65\%, Fe 42\%, Ni 81\%, Zn 82\%, Ag 56\%, Pb 46\%) within $72 \mathrm{~h}$ under laboratory conditions. The metal content of PCB after bioleaching was analyzed by ICP-MS. The crude PCB and bioleaching residue were characterized by FT-IR, XRD, SEM for the determination of structural and functional group changes for confirmation of bioleaching.
\end{abstract}

Conclusion: The findings of the present study concluded that Streptomyces albidoflavus TN10 is a promising candidate for bioleaching of heavy metals from the printed circuit board as an eco-friendly and cost-effective process.

Keywords: E-Waste, Printed circuit board, Heavy metals, Bioleaching, Streptomyces sp.

\section{Introduction}

Environmental pollution keeps on increasing at an alarming rate due to several man-made activities such as urbanization, technological advancement, unsafe agricultural practices and rapid industrialization (Ojuederie and Babalola 2017). Modern life is highly attracted to new and sophisticated electronic equipment with innovative technology. Moreover, the increasing necessities of mankind, the decreasing cost of electronics and the fast rate at which the outdated units are replaced have given rise to the generation of a new stream of waste known as E-waste which is rising three times higher than the other forms of municipal waste (Adie et al. 2014). Globally, about 50 million tons of e-waste are produced every year

\footnotetext{
*Correspondence: mrkactinos@gmail.com

${ }^{2}$ Centre for Drug Discovery and Development, Sathyabama Institute of Science and Technology, Chennai, Tamil Nadu 600 119, India Full list of author information is available at the end of the article
}

(Liu et al. 2016). Waste electrical and electronic equipment (WEEE), also called electronic waste or e-waste, has been attracting more and more concerns from scientists, entrepreneurs, journalists and governments all over the world (Yazici and Deveci 2013).

Printed circuit board is an important and essential component of all electronic and electrical equipment, containing lots of valuable metals together with the number of hazardous metals or minerals which can harm the environment as well as human health (Karwowska et al. 2014; Ilyas and Lee 2014; Willner et al. 2015). Therefore, there is an urgent need for the recovery of valuable metals from PCBs. Various processes, such as mechanical (Meng et al. 2017), pyrometallurgical (Jung et al. 2017), hydrometallurgical (Pant et al. 2012) and biometallurgical (Mrazikova et al. 2016; Priya and Hait 2017) process, are applied for the recovery of metals from PCBs. The recovery of heavy metals using pyrometallurgical and 
hydrometallurgical methods releases toxic gases such as dioxins and furans which affect the environmental and public health. Bioleaching is a promising technology that uses microorganisms to recover metals from PCB which is low cost and ecofriendly (Hong and Valix 2014). Among the all microorganisms being selected for bioleaching of metals from PCB, chemolithoautotrophs are commonly used for metal recovery from PCBs, such as Acidithiobacillus ferrooxidans, Leptospirillum ferrooxidans, Acidithiobacillus thiooxidans (Erust et al. 2013) and Chromobacterium violaceum (Li et al. 2015).

Actinobacteria are the group of ecologically abundant and metabolically multitalented bacteria that are widely distributed in nature including the metal-contaminated soils. They are well known for their ability to produce secondary metabolites and wealth of natural products with structural complexity and with diverse medicinal applications and properties (Abdelmohsen et al. 2014). Members of the phylum actinobacteria are well explored for their ability to degrade several recalcitrant chemicals like hydrocarbons, pesticides and industrial dyes (Polti et al. 2014). There are several studies which reported regarding the heavy metal resistance (Latha et al. 2015) and bioaccumulation (Lin et al. 2012) potential of actinobacterial genera, notably the genus Streptomyces. However, they are not much investigated for bioleaching of heavy metals from e-wastes including from PCBs. With this view, the present study focused on heavy metal bioleaching from printed circuit board using metal-resistant actinobacterium isolated from an insect nest, an understudied source.

\section{Materials and methods}

\section{Collection and processing of e-waste}

Printed circuit boards (PCBs) were collected from the e-waste dumping area at Chennai (Long. $80^{\circ} 7^{\prime} 39^{\prime \prime}$; Lat. $\left.12^{\circ} 55^{\prime} 37^{\prime \prime}\right)$, Tamil Nadu and India. No physical or mechanical separation process was used before transportation to the laboratory. Therefore, it is necessary to first remove as much of the chemical coating as possible. PCBs were transferred in $10-\mathrm{M} \mathrm{NaOH}$ solution and left undisturbed for $48 \mathrm{~h}$. Then, PCBs were taken out and washed under running tap water to remove the solder. The treated PCBs were kept in tray dryer for $40 \mathrm{~min}$ and finally sieved for fine powder with $120-\mu \mathrm{m}$ pore size for analysis and bioleaching (Jadhav et al. 2016).

\section{Determination of metal content of PCB}

Five grams of PCB powder was taken in 250-ml Erlenmeyer flask and mixed with 40-ml aqua-regia [a mixture of concentrated acid $(69 \% \mathrm{~m} / \mathrm{v})$ and hydrochloric acid $(37 \% \mathrm{~m} / \mathrm{v})$ at $1: 3$ ratios]. The mixture was allowed to stand for $24 \mathrm{~h}$ and centrifugation was carried out at
$5000 \mathrm{rpm}$ for $15 \mathrm{~min}$. The digested PCB solution was then filtered through a $0.45-\mu \mathrm{m}$ membrane filter. The metal concentration of $\mathrm{PCB}$ powder was analyzed using ICP-MS (Agilent 7700X ICP-MS G3281A) (Yamane et al. 2011).

\section{Description of actinobacterial strain}

Actinobacterial strains for bioleaching studies were obtained from the Bioprospecting division, Centre for Drug Discovery and Development, Sathyabama Institute of Science and Technology, Chennai, Tamil Nadu, India. All the strains were previously isolated from termite nest (Lat.79.69; Long.12.83) collected from Kanchipuram, Tamil Nadu, India. Pure cultures of all the strains were maintained in ISP 2 medium as well as in 30\% glycerol stored at $-20{ }^{\circ} \mathrm{C}$ for further studies (Radhakrishnan et al. 2014).

\section{Screening and identification of heavy metal resistance actinobacteria}

The metal tolerance pattern of actinobacterial strains was determined by the minimum inhibitory concentration (MIC) approach. ISP2 agar plates with 100-1500 ppm of heavy metal $\left(\mathrm{FeSO}_{4}, \mathrm{CuSO}_{4}\right.$, and $\left.\mathrm{NiCl}_{3}\right)$ concentrations were prepared. Spores of actinobacterial strains were inoculated on all the heavy metal-supplemented ISP2 agar plates as a spot. The growth of actinobacterial strains was observed after incubation at $28{ }^{\circ} \mathrm{C}$ for 1 week and their heavy metal-resistant properties were recorded. For identification, microscopic, cultural and physiological characteristics of strain TN10 were studied described by Shirling and Gottileb (1966) and Radhakrishnan et al. (2013). Effect of physiological conditions like the addition of sugars, aminoacid, $\mathrm{pH}$, temperature $\left({ }^{\circ} \mathrm{C}\right)$ and $\mathrm{NaCl}$ concentration of potential actinobacterial strain TN10 was also studied. For the 16s rRNA sequence analysis, genomic DNA from the actinobacterial strain TN10 was isolated using solute ready genomic DNA kit. Concentration and purity of the extracted DNA were then evaluated by running on agarose gel and by NanoDrop (Thermo Scientific) readings. The genomic DNA obtained from the actinobacterial strain TN10 was further subjected to PCR amplification of $16 \mathrm{~S}$ rRNA gene using the primers 8F (5'-AGA GTT TGA TCC TGG CTC AG-3') and 1492R (5'-GGT TAC CTT GTT ACG ACT T-3') (Lane 1991). The reaction mixture $(50 \mu \mathrm{l})$ consisted of $100 \mathrm{ng}$ of 2 - $\mu$ l genomic DNA, $5 \mu \mathrm{l}$ of $10 \times$ buffer, $4 \mu \mathrm{l}$ of BSA ( $1 \mathrm{mg}$ / $\mathrm{ml}), 1 \mu \mathrm{l}$ of dNTP mixture ( $25 \mathrm{mM}), 1 \mu \mathrm{l}$ of each primer $(10 \mu \mathrm{M})$ and $3.5 \mathrm{U}$ of Taq DNA polymerase. PCR condition provided as $6 \mathrm{~min}$ at $94{ }^{\circ} \mathrm{C}$ followed by 35 cycles of $45 \mathrm{~s}$ at $94{ }^{\circ} \mathrm{C}, 45 \mathrm{~s}$ at $55^{\circ} \mathrm{C}$ and $1.5 \mathrm{~min}$ at $72{ }^{\circ} \mathrm{C}$, followed by an $8 \mathrm{~min}$ extension at $72^{\circ} \mathrm{C}$. PCR amplification was performed in an Eppendorf Master cycler Gradient. 
Purified PCR product was sequenced bi-directionally to obtain complete coverage at Eurofins Genomics, Bangalore. Sequences were edited and contig was assembled in DNA baser v. 3 and compared with GenBank sequences by BLAST analysis. The $16 \mathrm{~S}$ rRNA gene sequence was aligned with selected sequences obtained from the GenBank using the CLC sequence viewer 6.0 program. Phylogeny prediction was done using MEGA 7 software (Saitou and Nei 1987). The confidence values for the branches of the phylogenetic tree were determined using bootstrap analyses (Felsenstein 1985) based on 1000 resampling of the neighbor-joining data set. The partial $16 \mathrm{~S}$ rRNA nucleotide sequence of the potential actinobacterial strain TN10 was deposited in the GenBank database.

\section{Bioleaching of heavy metals from the printed circuit board (PCB)}

Actinobacterial strain TN10, that showed resistance to the most concentration of significant metals in primary screening, was inoculated into $200 \mathrm{ml}$ of yeast extract malt extract broth in 500-ml conical flask and incubated at $28{ }^{\circ} \mathrm{C}$ in $120 \mathrm{rpm}$ in shaking incubator for $24-48 \mathrm{~h}$. After incubation, the cells were separated by centrifugation of culture broth at 10,000 rpm for $10 \mathrm{~min}$. The pellet was taken and washed two times with sterile distilled water. One gram of crude PCB powder was added into each $150 \mathrm{ml}$ of ISP 2 broth medium taken in three $500-\mathrm{ml}$ conical flasks and $\mathrm{pH}$ of the medium was adjusted to 5 , 6 and 7, respectively. Then, 48-h fresh culture of actinobacterial strain TN10 was inoculated into PCB containing solution. The flasks were kept in a rotary shaker at $110 \mathrm{rpm}$ for $120 \mathrm{~h}$. Then, the sample was drawn aseptically at every $24 \mathrm{~h}$. Cells were separated by centrifugation at $10,000 \mathrm{rpm}$ for $20 \mathrm{~min}$ and the cell-free supernatant was collected in clean tubes and used for analysis. Bioleaching of heavy metals from the crude PCB was determined by ICP-MS analysis (Agilent 7700X ICP-MS instrument (Model\#-G3281A) The percentage of heavy metals accumulation was calculated using the formula (Jadhav et al. 2016). \% heavy metal extraction=Initial metal content - metal content after leaching/initial metal content $\times 100$.

\section{Characterization of $\mathrm{PCB}$ and bioleaching residue SEM analysis}

Dried PCB powder and its bioleaching residue were subjected to SEM analysis by the following method of Ijadi Bajestani et al. (2014). The bioleaching residue was washed five times and then dried at $80{ }^{\circ} \mathrm{C}$. $\mathrm{PCB}$ and bioleached residue were mounted with $2.5 \%$ glutaraldehyde for $60 \mathrm{~min}$ and washed with $0.1-\mathrm{M}$ sodium acetate buffer ( $\mathrm{pH}$ 7.3). Sample was dehydrated over an ethanol gradient and examined with a QUANTA 200(Netherlands).

\section{$X R D$ analysis}

XRD pattern of PCB powder and its bioleached residue was analyzed by adopting the method described by Wang et al. (2011) with a slight modification and the peaks from the results were compared by standards of JCPDS records (Garg et al. 2019).

\section{FT-IR analysis}

Dried PCB and the bioleaching residues were investigated by Fourier transform infrared spectroscopic (FTIR) analysis. The bioleaching residues were taken and centrifuged at 15,000 rpm for $15 \mathrm{~min}$ and the pellets were washed three times with phosphate buffer $(\mathrm{pH}$ 7.0) and dried in $60{ }^{\circ} \mathrm{C}$. The dried PCB and bioleached residue were mixed with spectroscopically pure $\mathrm{KBr}$ in the ratio of 2:200, pellets were fixed in a sample holder and the analyses were carried out using Perkin Elmer Spectrum RXI FTIR Spectrometer in the mid-IR region of $400-4000 \mathrm{~cm}^{-1}$ with 16 scan speed (Xia et al. 2018).

\section{Statistical analysis}

Bioleaching experiments are conducted in triplicates $(n=3)$ and the percentage of metal removal from the printed circuit board was calculated with error bars. Both mean and standard deviation were performed where appropriate, using the statistical package with graph bad prism version 8 .

\section{Result and discussion}

Sample collection and determination of metal content of PCB

E-waste is one of the important sources of heavy metal pollution which contains a wide range of metals including precious metals like gold and silver, hazardous metals like arsenic and mercury, and base metals like copper and nickel (Pradeepa et al. 2017). The waste discarded PCBs were collected from Chennai corporation waste disposal site. Chennai is one of the four metropolitan cities in India and is a large generator of e-waste by numerous industries. The heavy metals present in the collected PCB are given in (Table 1). The results of ICP-MS analysis showed that copper $(\mathrm{Cu})$ is the most precious metal present in a high amount $(97.663 \mathrm{mg} / \mathrm{g})$. Copper $(\mathrm{Cu})$ is the most abundant metal present in PCB (Shah et al. 
Table 1 Elemental composition of printed circuit board

\begin{tabular}{llcc}
\hline S.no & Elements & $\begin{array}{l}\text { Concentration } \\
(\mathbf{m g} / \mathbf{g})\end{array}$ & $\begin{array}{l}\text { After } \\
\text { bioleaching } \\
\text { (mg/g) }\end{array}$ \\
\hline 1 & $\mathrm{Al}$ & 2.907 & 0.918 \\
2 & $\mathrm{Ca}$ & 1.384 & 0.623 \\
3 & $\mathrm{Cu}$ & 97.663 & 28.83 \\
4 & $\mathrm{Cd}$ & 0.211 & 0.098 \\
5 & $\mathrm{Fe}$ & 18.309 & 10.39 \\
6 & $\mathrm{Ni}$ & 1.231 & 0.838 \\
7 & $\mathrm{Zn}$ & 3.226 & 0.716 \\
8 & $\mathrm{Ag}$ & 25.8 & 11.09 \\
9 & $\mathrm{~Pb}$ & 18.262 & 10.365 \\
10 & $\mathrm{Hg}$ & 17.56 & 9.43 \\
\hline
\end{tabular}

2014). Usha et al. (2017) reported that the copper $(\mathrm{Cu})$ is the most base metal present in a high amount $(19.0 \mathrm{mg} / \mathrm{l})$ in waste-discarded printed circuit board.

\section{Screening and identification of heavy metal resistance actinobacteria}

The cultural characteristics of five actinobacterial strains are shown in Table 2. Heavy metal-resistant property of actinobacterial strains was screened by adopting the dot plot assay method. The growth of actinobacterial strains on different concentrations of selected heavy metals is given in Table 3 . The results showed that strain TN10 showed resistance to a maximum of 1500 ppm concentration of $\mathrm{FeSO}_{4}, \mathrm{CuSO}_{4}$, and $\mathrm{NiCl}_{3}$. Actinobacterial genera notably Streptomyces sp. are widely distributed in heavy metal-contaminated soil and it showed high resistance to toxic heavy metals and used as a bio-sorbent in the removal of heavy metals from the pollutants). Previously, El Baz et al. (2015) isolated the heavy metalresistant Streptomyces sp. for removal of copper and nickel from metal-polluted soil. Madden et al. (2013) have reported the isolation of actinobacteria from Paper Wasp (Hymenoptera:Vespidae:Polistinae) nests for antimicrobial application. However, this is the first attempt using actinobacteria from insect nest for bioleaching of heavy metals from PCB. For identification strain, TN10 showed the presence of both aerial and substrate mycelium with no fragmentation in microscopic observation, and showed good growth on ISP2 agar with powdery consistency (Additional file 1: Fig. S1). Physiological characteristics of strain TN10 are given in Additional file 1: Table S1. Potential actinobacterial strain TN10 subjected to amplification of partial 16S rRNA gene and the obtained sequence with the length of 1420 base pair was identified as Streptomyces species. The potential Streptomyces strain TN10 was submitted to NCBI Genbank and assigned the accession number MH021968. The

Table 2 Morphological characteristics of actinobacteria strains

\begin{tabular}{|c|c|c|c|c|c|c|c|c|}
\hline \multirow[t]{2}{*}{ S. no } & \multirow[t]{2}{*}{ Strain no } & \multicolumn{7}{|c|}{ Cultural characteristics } \\
\hline & & Growth & Consistency & AMC & RSP & SP & AM & SM \\
\hline 1 & TN 10 & Good & Rough & White & Pale yellow & - & + & + \\
\hline 2 & TN 5 & Good & Powdery & White & Pale yellow & - & + & + \\
\hline 3 & TN 2 & Good & Leathery & Pale yellow/dirty & Brown & - & + & + \\
\hline 4 & TN 14 & Good & Rough & Yellowish gray & Orange & + & + & + \\
\hline 5 & TN 8 & Good & Leathery & Dirty white & Reddish brown & - & + & + \\
\hline
\end{tabular}

+, present; -, absent; AMC, aerial mass color; RSP, reverse side pigment; SP, soluble pigment; AM, aerial mycelium; SM, substrate mycelium

Table 3 Screening of actinobacterial strains for metal resistant properties

\begin{tabular}{|c|c|c|c|c|c|c|c|c|c|c|c|c|c|}
\hline \multirow[t]{2}{*}{ S. no } & \multirow[t]{2}{*}{ Strain no } & \multicolumn{4}{|c|}{$\begin{array}{l}\text { Concentration of ferrous sulfate } \mathrm{FeSO}_{4} \\
(\mathrm{ppm})\end{array}$} & \multicolumn{4}{|c|}{$\begin{array}{l}\text { Concentration of copper sulfate } \mathrm{CuSO}_{4} \\
\text { (ppm) }\end{array}$} & \multicolumn{4}{|c|}{$\begin{array}{l}\text { Concentration of nickel chloride } \\
\mathrm{NiCL}_{3}(p p m)\end{array}$} \\
\hline & & 100 & 500 & 1000 & 1500 & 100 & 500 & 1000 & 1500 & 100 & 500 & 1000 & 1500 \\
\hline 1 & TN 10 & +++ & +++ & +++ & +++ & +++ & +++ & +++ & +++ & +++ & +++ & +++ & + \\
\hline 2 & TN 5 & +++ & +++ & + & - & +++ & +++ & +++ & - & +++ & + & + & - \\
\hline 3 & TN 2 & +++ & +++ & + & - & +++ & +++ & + & - & +++ & ++ & + & - \\
\hline 4 & TN 14 & +++ & +++ & +++ & - & +++ & +++ & + & - & +++ & ++ & + & - \\
\hline 5 & TN 8 & +++ & + & + & - & +++ & +++ & +++ & - & +++ & +++ & ++ & + \\
\hline
\end{tabular}

+++ , excellent growth; ++ , good growth; + , moderate growth;,- no growth 


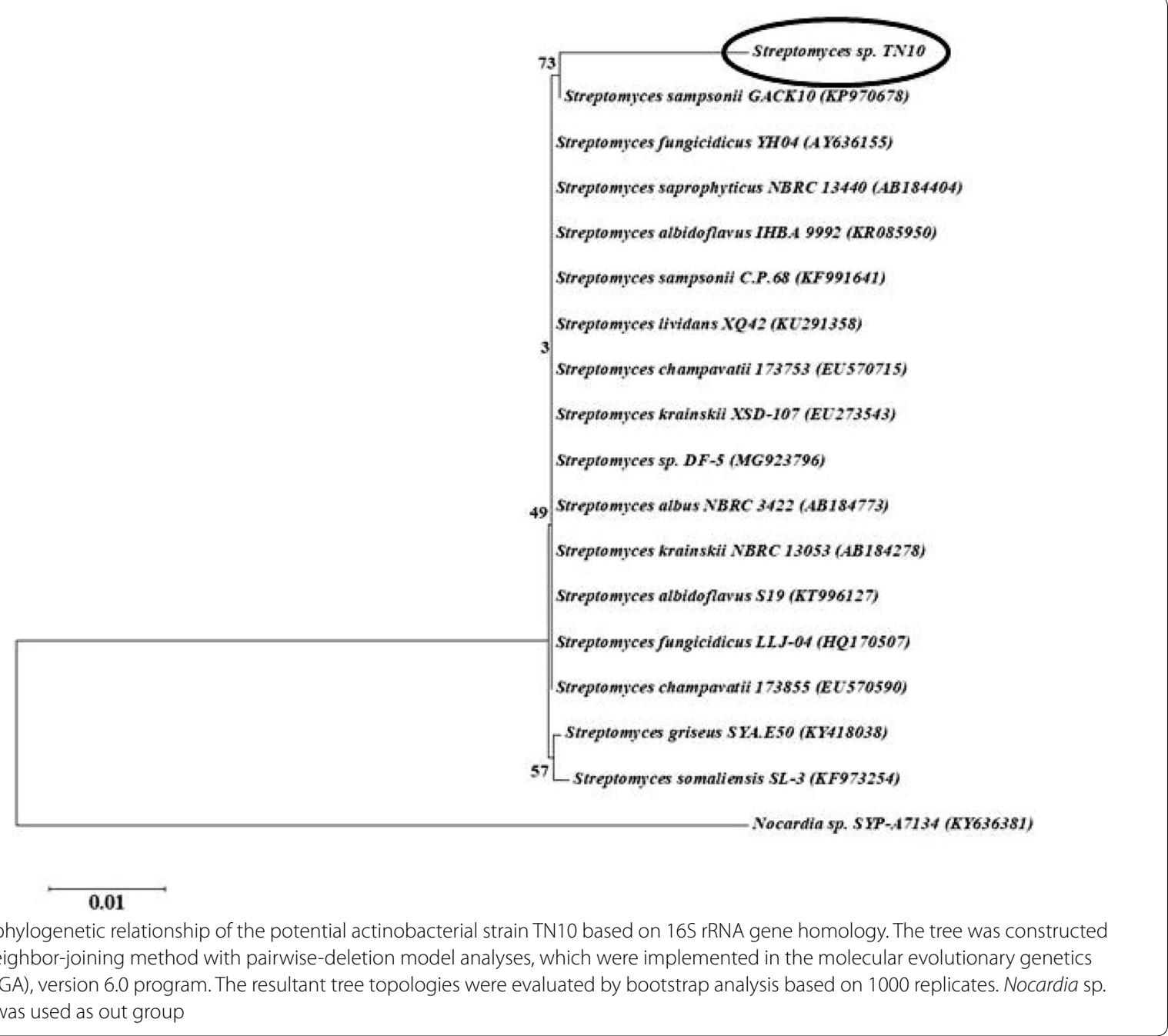

constructed phylogenetic tree clearly showed that strain TN10 is closely related to Streptomyces albidoflavus with the highest similarities (Fig. 1). Previously, several authors have reported the bioleaching potential of Streptomyces sp. isolated from different ecosystem ex (Brzezinskaa et al. 2013; Long et al. 2018; Daboor et al. 2014; El Baz et al. 2015). However, no previous evidence has been reported on bioleaching of heavy metals in printed circuit boards by Streptomyces albidoflavus.

\section{Bioleaching of heavy metals from PCB}

Heavy metals present in PCB were bioleached by adopting the shake flask method. Actinobacterial strain TN 10 showed the good growth in $\mathrm{pH} \mathrm{5,6}$ and 7. The maximum metal recovery were observed at $\mathrm{pH} 6$ with zinc $(\mathrm{Zn})$ in maximum $82.42 \pm 1.32 \%$ in $72 \mathrm{~h}$ of incubation period followed by nickel (Ni) $81.23 \pm 0.45 \%$ and least recovery was shown in Fe $42.60 \pm 1.7 \%$ (Fig. 2b). The percentage of metal recovery was decreased in pH 5 and 7 (Fig. 2a, c). Similar findings were reported by Jadhav et al. (2016) that the maximum level of zinc extraction is $98 \%$ by Aspergillus niger supernatant with $0.1 \mathrm{M}$ of $\mathrm{NaOH}$. Chen and Huang (2014) reported recovery of copper $65 \%$ and nickel $100 \%$ in PCB wastewater sludge by $S$. thermosulfidooxidans. Previously, several studies have identified many fungal or bacterial strains with the capability to leaching heavy metals from PCB. The comparison of bioleaching potential of Streptomyces sp. TN10 with some of the previous studies shows that the strain TN10 has the capability of recovering higher concentration of heavy metals than most of the previously published microorganisms (Table 4). 


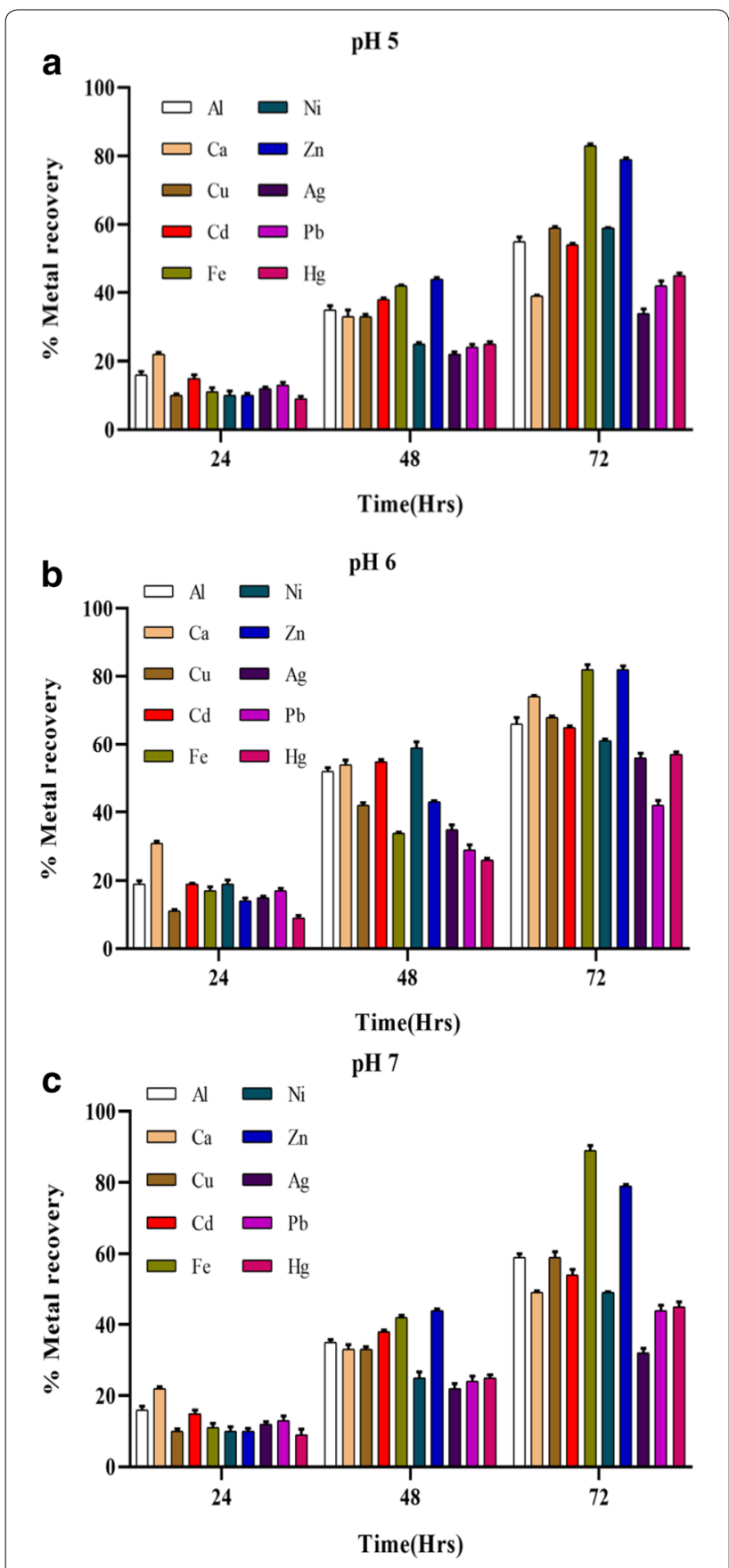

Fig. 2 Bioleaching of heavy metals from $\mathrm{PCB}(\mathbf{a} \mathrm{pH} 5, \mathbf{b} \mathrm{pH} 6, \mathbf{c} \mathrm{pH}$ 7)

\section{Characterization of $\mathrm{PCB}$ and bioleaching residue SEM analysis of $P C B$ and bioleaching residue}

Scanning electron microscope (QUANTA 200) was used to determine the structural morphology of raw $\mathrm{PCB}$ and bioleaching residue. The SEM image of PCB were showed in Fig. 3a which denotes the crystalline rod structures and spherical with a rough surface. After bioleaching, heavy metals present in the PCB were changed to granular shape with smooth surface (Fig. 3b). This structural change confirms that heavy metals in the printed circuit board were bioleached by Streptomyces sp. Previously Zhao et al. (2008) observed the structural changes in the PCB after the bioleaching has been identified by scanning electron microscope analysis.

\section{$X R D$ analysis}

$X R D$ is the foremost technique used for detecting the elements present in the sample. XRD results of PCB powder have unveiled five different peaks $22.33,34.23,40.45$, $44.55,66.81$ corresponding to (581), (491), (464), (438) and (381) (Fig. 4a); whereas, our bioleaching residue unveiled seven values $22.19,31.88,45.51,56.73,66.39$, $75.45,81.20$ with corresponding peaks (684), (783), (592), (442), (391), (393) and (361) both are having many similarities (Fig. 4b). Based on the peak size, the sizes of the metal are detected from 0 to 3802 -h peak. The peak from 31.88 to 75.45 denotes the presence of $\mathrm{Ag}$ and $\mathrm{Hg}$. The present findings of the analysis were similarly reported by Das et al. (2009).

\section{FT-IR spectra of bioleaching residue and $P C B$ powder}

The FTIR spectrum of e-waste (printed circuit board and bioleaching residue) is represented in (Fig. 5). The broad absorption peak of PCB powder around $3382 \mathrm{~cm}^{-1}$ is related to $\mathrm{O}-\mathrm{H}$ stretching vibration band but after the bioleaching residue, there is a broad adsorption shift in a peak at $3409 \mathrm{~cm}^{-1}$ at the same stretching and the next $2924 \mathrm{~cm}^{-1}$ peak proves the existence of $\mathrm{C}-\mathrm{H}$ stretching vibration both in $\mathrm{PCB}$ and bioleaching residue. Furthermore, $\left(1612,1094,2307,1640 \mathrm{~cm}^{-1}\right)$ peak attributes to the presence of $\mathrm{C}=\mathrm{O} \mathrm{C}=\mathrm{C} / \mathrm{CN}$ and $\mathrm{RCO}-\mathrm{OH}$ stretching vibration. The above findings from FT-IR spectrum confirmed that citric acid and oxalic acid are the main reason for the decreasing $\mathrm{pH}$ during bioleaching. The PCB powder exhibits the metal group due to $\mathrm{CH} 2$ rocking vibration at $895 \mathrm{~cm}^{-1}$ and the bioleached residue at $816 \mathrm{~cm}^{-1}$. The peaks at 1464 and $1431 \mathrm{~cm}^{-1}$ are the deformation vibrations. The bioleaching residue has more skeletal vibration at 590,446, 433, $411 \mathrm{~cm}^{-1}$ than the PCB powder at $419 \mathrm{~cm}^{-1}$. The rocking vibration peak arises at $1031 \mathrm{~cm}^{-1}$ in the bioleaching residue. Finally, the peak at $617 \mathrm{~cm}^{-1}$ corresponds to $\mathrm{C}-\mathrm{H}$ wagging vibrations. Previously, Willner (2012) and Narayanasamy et al. (2018) reported the similar results that organic acids are 


\section{Table 4 Bioleaching of heavy metals from printed circuit board by several microorganisms}

\begin{tabular}{|c|c|c|c|}
\hline S. no & $\begin{array}{l}\text { Microorganisms used for bioleaching of heavy } \\
\text { metals from PCB }\end{array}$ & Metals extraction (\%) & References \\
\hline 1 & $\begin{array}{l}\text { Leptospirillum ferriphilum and Sulfobacillus thermosulf- } \\
\text { dooxidans. }\end{array}$ & $\mathrm{Cu}(100)$ & Wu et al. (2018) \\
\hline 2 & Acidithiobacillus thiooxidans & Zn(69) Cu(9) Pb(3) Cd(99), Ni(53), Cr(13) & Karwowska et al. (2014) \\
\hline 3 & S. acidophilus & $\mathrm{Zn}(100), \mathrm{Cu}(65)$ & Chen and Huang (2014) \\
\hline 4 & Aspergillus niger & Gold (Au)-56 & Delira et al. (2019) \\
\hline 5 & Acidithiobacillus ferrooxidans & Copper(Cu)-80 & Choi et al. (2004) \\
\hline 6 & A. niger & $\begin{array}{l}\text { Cu (99), Mg (99), Ti (98), Mn (84), Zn (82), Sn (78), Ni (76), } \\
\text { As (76), Sr (73), Cd (72), Co (72), Ag (72), Al (70), Si (70), } \\
\text { Pb (65), B (63), Fe (61), Pd (40), Au (30) }\end{array}$ & Jadhav et al. (2016) \\
\hline 7 & Leptospirillum ferriphilum & $\mathrm{Cu}(60.33), \mathrm{Zn}(75.67), \mathrm{Ni}(71.09)$ & Shah et al. (2014) \\
\hline 8 & Sulfobacillus thermosulfidooxidans & $\mathrm{Cu}(80)$ & Rodrigues et al. (2015) \\
\hline 9 & A. thiooxidans & $\mathrm{Cu}(100), \mathrm{Ni}(92), \mathrm{Zn}(89), \mathrm{Al}(20)$ & Mrazikova et al. (2015) \\
\hline 10 & Sulfobacillus thermosulfidooxidans & $\mathrm{Ni}(81), \mathrm{Cu}(89), \mathrm{Al}(79), \mathrm{Zn}(83)$ & Ilyas et al. (2007) \\
\hline 11 & Shewanella sp. & Cu and $\mathrm{Ni}(49)$ & Kim et al. (2018) \\
\hline 12 & Chromobacterium violaceum & $\mathrm{Au}(70)$ & Li et al. (2015) \\
\hline 13 & Chromobacterium violaceum & $\mathrm{Cu}(76), \mathrm{Au}(69), \mathrm{Zn}(46), \mathrm{Fe}(9), \mathrm{Ag}(7)$ & Pradhan and Kumar (2012) \\
\hline 14 & Mixture of chromobacterium violaceum and $P$. aeruginosa & $\mathrm{Cu}(83), \mathrm{Au}(73), \mathrm{Zn}(49), \mathrm{Fe}(9), \mathrm{Ag}(7)$ & Pradhan and Kumar (2012) \\
\hline 15 & Acidithiobacillus ferrooxidans & $\mathrm{Ni}(86)$ & Mrazikova et al. (2014) \\
\hline 16 & Acidithiobacillus thiooxidans & $\mathrm{Cu}(60)$ & Mrazikova et al. (2013) \\
\hline 17 & Aspergillus niger MXPE6 & $\mathrm{Cu}(28), \mathrm{Au}(83), \mathrm{Ni}(14)$ & Madrigal-Arias et al. (2015) \\
\hline 18 & Chromobacterium violaceum & Au (11.31) and Cu (24.6) & Brandl et al. (2008) \\
\hline 19 & Pseudomonas chlororaphis & $\mathrm{Au}$ (8.2), Cu (52.3) and $\mathrm{Ag}(12.1)$ & Ruan et al. (2014) \\
\hline 20 & Acidithiobacillus ferrooxidans & Cu (96.8), Zn (83.8), and Al (75.4) & Yanga et al. (2014) \\
\hline 21 & Chromobacterium violaceum & $\mathrm{Au}(22.5)$ & Natarajan and Ting (2014) \\
\hline 22 & $\begin{array}{l}\text { Sulfobacillus thermosulfidooxidans and Thermoplasma } \\
\text { acidophilim }\end{array}$ & $\mathrm{Cu}(86), \mathrm{Zn}(80), \mathrm{Al}(64)$ and $\mathrm{Ni}(74)$ & Ilyas et al. (2010) \\
\hline 23 & Acidiphilium acidophilum (ATCC 27807) & $\mathrm{Cu}(3.6)$ and $\mathrm{Ni}(86)$ & Das (2010) \\
\hline 24 & Acidithiobacillus sp. and Leptospirillum sp. & Cu and $\mathrm{Ni}(100)$ & Vestola et al. (2010) \\
\hline 25 & Acidithiobacillus thiooxidans & $\mathrm{Cu}(98)$ & Hong and Valix (2014) \\
\hline 26 & Acidithiobacillus thiooxidans & $\mathrm{Cu}(74)$ & Bas et al. (2013) \\
\hline 27 & Acidithiobacillus ferroxidans & $\mathrm{Cu}(99)$ & Yang et al. (2009) \\
\hline 28 & Acidithiobacillus ferroxidans & $\mathrm{Cu}(99)$ & Wang et al. (2009) \\
\hline 29 & Thiobacillus thiooxidans and Thiobacillus ferrooxidans & $\mathrm{Cu}, \mathrm{Ni}, \mathrm{Al}$ and $\mathrm{Zn}(90)$ & Brandl et al. (2001) \\
\hline 30 & Aspergillus niger, Penicillium simplicissimum & $\begin{array}{l}\text { Cu and } \mathrm{Sn} \text { by } 65 \% \text {, and } \mathrm{Al}, \mathrm{Ni}, \mathrm{Pb} \text {, and } \mathrm{Zn} \text { by more than } \\
95 \%\end{array}$ & Brandl et al. (2001) \\
\hline 31 & Pseudomonas balearica SAE1 & $A u(73)$ and $A g(41.6)$ & Kumar et al. (2018) \\
\hline 32 & Acidithiobacillus ferrooxidans & $\mathrm{Cu}(100), \mathrm{Ni}(90)$ and $\mathrm{Zn}(65)$ & Gorecka et al. (2019) \\
\hline 33 & $\begin{array}{l}\text { Acidithiobacillus ferrooxidans and Acidithiobacillus } \\
\text { thiooxidans }\end{array}$ & $\mathrm{Cu}(81), \mathrm{Pb}(69)$ and $\mathrm{Ni}(61)$ & Lin et al. (2010) \\
\hline 34 & Acidithiobacillus ferrooxidans & $\mathrm{Cu}(90.15)$ & Weihua et al. (2014) \\
\hline 35 & Sulfobacillus thermosulfidoooxidans & $\mathrm{Cu}(89), \mathrm{Ni}(81)$, and $\mathrm{Zn}(83)$ & Ilyas et al. (2007) \\
\hline 36 & Gallionella sp. and leptospiullam sp. & $\mathrm{Cu}(95)$ & Oguchi et al. (2012) \\
\hline 37 & $\begin{array}{l}\text { Acidithiobacillus thiooxidans, Thiobacillus sp., Bacillus } \\
\text { subtilis and Bacillus cerus }\end{array}$ & $\mathrm{Cu}(53), \mathrm{Ni}(48.5)$ and $\mathrm{Zn}(48)$ & Karwowska et al. (2014) \\
\hline 38 & Sulfobacillus thermosulfidoooxidans & $\mathrm{Cu}(95), \mathrm{Al}(91)$ and $\mathrm{Zn}(96)$ & Ilyas et al. (2013) \\
\hline 39 & Acidithiobacillus ferrooxidans & $\mathrm{Cu}(97), \mathrm{Al}(75)$ and $\mathrm{Zn}(84)$ & Sun et al. (2017) \\
\hline 40 & Streptomyces albidoflavus TN10 & $\begin{array}{l}\mathrm{Al}(66), \mathrm{Ca}(74), \mathrm{Cu}(68), \mathrm{Cd}(65), \mathrm{Fe}(42), \mathrm{Ni}(81), \mathrm{Zn}(82) \\
\mathrm{Ag}(56), \mathrm{Pb}(46), \mathrm{Hg}(59)\end{array}$ & This study \\
\hline
\end{tabular}




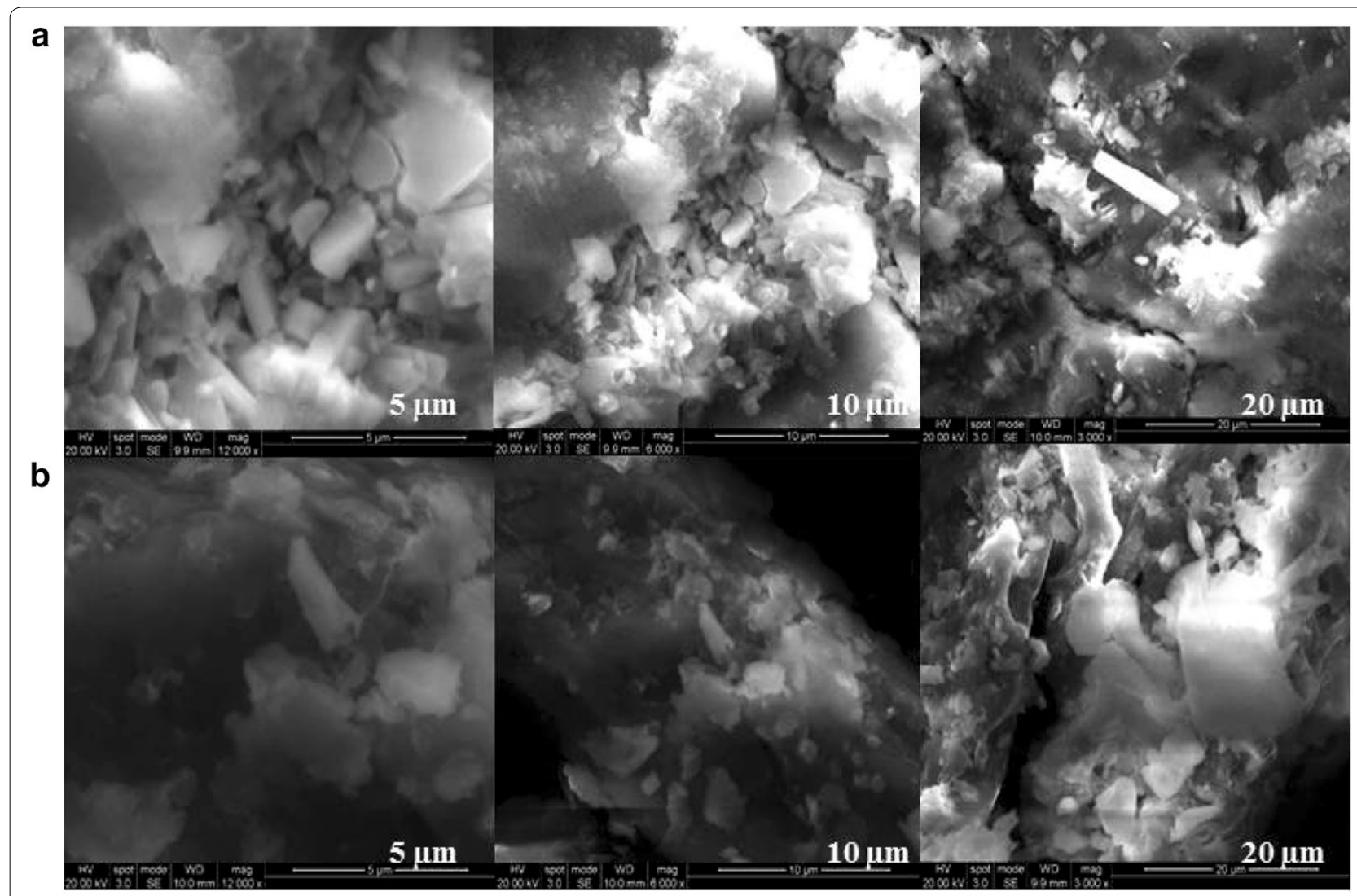

Fig. 3 Scanning electron microscope images a raw PCB, b bioleaching residue

possible reason for reduction of $\mathrm{pH}$ during bioleaching process.

\section{Conclusion}

The findings of the current study revealed that $\mathrm{pH}$ plays an important role in metal recovery using actinobacterial strain. The quantities of metal concentration were decreased from initial concentration because of the detoxification process by actinobacterial strain TN10.
PCB and Bioleaching residues were characterized by SEM, FTIR and XRD. The results from this study provide the importance of metals recovery from the e-waste (PCBs) and using actinobacteria in bioleaching. From our study, we concluded that the actinobacterium Streptomyces albidoflavus TN10 can be used as an alternative biological candidate for the removal of metals from discarded PCBs with both economic and environmental perspectives. 

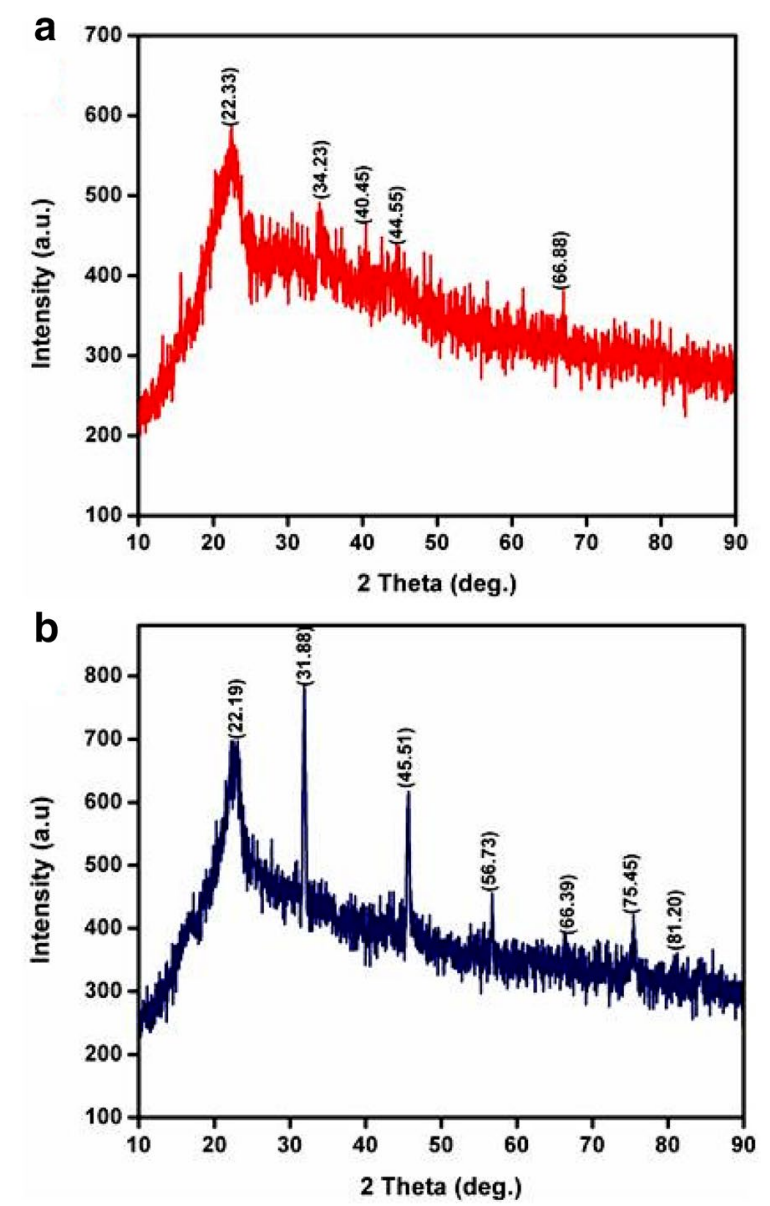

Fig. 4 XRD spectrum a raw $P C B$, b bioleaching residue

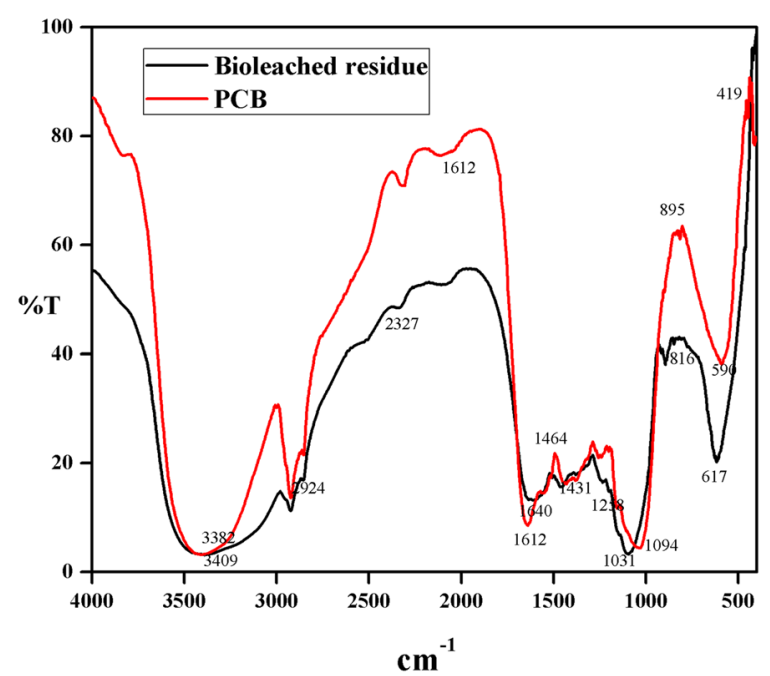

Fig. 5 FTIR spectrum of PCB and bioleaching residue

\section{Supplementary information}

Supplementary information accompanies this paper at https://doi. org/10.1186/s40643-019-0283-3.

Additional file 1: Figure S1. Colony and micromorphology of actinobacterial strain TN10. Table S1. Physiological characteristics of potential actinobacterial strain TN10.

\section{Abbreviations}

PCB: printed circuit board; ICP-MS: inductively coupled plasma mass spectrometry; ISP: International Streptomyces Project; SEM: scanning electron microscope; XRD: X-ray powder diffraction; JCPDS: Joint Committee Powder diffraction Standards; FTIR: Fourier-transform infrared spectroscopy; Cu: copper; Al: aluminum; Sn: tin; Pb: lead; B: boron; Fe: iron; Si: silicon; Mg: magnesium; Ti: titanium; Ni: nickel; Sr: strontium; Zn: zinc; As: arsenic; Mn: manganese; Co: cobalt; Cd: cadmium; Pd: palladium; Au: gold; Ag: silver.

\section{Acknowledgements}

Authors gratefully acknowledge the management of Sathyabama Institute of Science and Technology, Chennai, Tamil Nadu, India for providing the research facilities. We are also thankful to the Centre for Life Science, Defence Research Development Organization, Bharathiyar University Campus, Coimbatore, Tamil Nadu, India for their kind support for SEM and XRD analysis.

\section{Authors' contributions}

DK, MR designed the experiment; VA, MK wrote the manuscript; ARA and JJ conducted the experiment; ST interpreted the result; $V G$ and RM corrected. All authors read and approved the final manuscript.

\section{Funding}

Not applicable.

\section{Availability of data and materials}

Not applicable.

\section{Ethics approval and consent to participate}

All the authors have read and agreed on the ethics for publishing the manuscript.

\section{Consent for publication}

The authors approved the consent for publishing the manuscript.

\section{Competing interests}

The authors declare that they have no competing interests.

\section{Author details}

${ }^{1}$ Department of Chemical Engineering, Sathyabama Institute of Science and Technology, Chennai, Tamil Nadu 600 119, India. ${ }^{2}$ Centre for Drug Discovery and Development, Sathyabama Institute of Science and Technology, Chennai, Tamil Nadu 600 119, India. ${ }^{3}$ DRDO-BU Centre for Life Sciences, Bharathiar University Campus, Coimbatore, Tamil Nadu 641 046, India.

Received: 15 July 2019 Accepted: 19 November 2019

Published online: 30 November 2019

\section{References}

Abdelmohsen UR, Bayer K, Hentschel U (2014) Diversity abundance and natural products of marine sponge-associated actinomycetes. Nat Prod Rep 31:381-399

Adie G, Balogun O, Li J, Osibanjo O (2014) Trends in toxic metal levels in discarded laptop printed circuit boards. Adv Mat Res 878:413-419

Bas AD, Deveci H, Yazici EY (2013) Bioleaching of copper from low grade scrap TV circuit boards using mesophilic bacteria. Hydrometallurgy 138:65-70 
Brandl H, Bosshard R, Wegmann M (2001) Computer-munching microbes: metal leaching from electronic scrap by bacteria and fungi. Hydrometallurgy 59:319-326

Brandl H, Lehmann S, Faramarzi MA, Martinelli D (2008) Biomobilization of silver, gold, and platinum from solid waste materials by $\mathrm{HCN}$-forming microorganisms. Hydrometallurgy 94:14-17

Brzezinskaa S, Jankiewiczb U, Burkowska A (2013) Purification and characterization of Streptomyces albidoflavus antifungal components. Appl Biochem Micro 49:451-457. https://doi.org/10.1134/S00036838130500 25

Chen Shen-Yi, Huang Qiao-Ying (2014) Heavy metals recovery from printed circuit board industry wastewater sludge by thermophilic bioleaching process. J Chem Technol Biotechnol 89:158-164

Choi MS, Cho KS, Kim DS, Kim DJ (2004) Microbial recovery of copper from printed circuit boards of waste computer by Acidithiobacillus ferrooxidans. J Environ Sci Health A Tox Hazard Subst Environ Eng 39:2973-2982

Daboor S, Mohamed Haroon A, Abd Elfatah Esmael N, Ibrahem Hanona S (2014) Heavy metal adsorption of Streptomyces chromofuscus K101. J Coast Life Med 2:431-437

Das N (2010) Recovery of precious metals through biosorption - a review. Hydrometallurgy 103:180-189

Das A, Vidyadhar A, Mehrotra SP (2009) A novel flow sheet for the recovery of metal values from waste printed circuit boards. Resour Conserv Recycl 53:464-469

Delira RA, Gómez-Martínez MJ, Soto BJ (2019) Gold bioleaching from printed circuit boards of mobile phones by Aspergillus niger in a culture without agitation and with glucose as a carbon source. Metals 9:521. https://doi. org/10.3390/met9050521

El Baz S, Baz M, Barakate M, Hassani L, ElGharmali A, Imziln B (2015) Resistance to and accumulation of heavy metals by Actinobacteria isolated from abandoned mining areas. Sci World J 14:761834. https://doi. org/10.1155/2015/761834

Erust C, Akcil A, Gahan CS, Tuncuk A, Deveci H (2013) Biohydrometallurgy of secondary metal resources: a potential alternative approach for metal recovery. J Chem Technol Biotechnol 88:2115-2132

Felsenstein J (1985) Confidence limits on phylogenies: an approach using the bootstrap. Evolution 39:783-791

Garg H, Nagar N, Dash A, Gahan GS (2019) Efficiency assessment of pure Fe oxidizing microorganisms in iron supplemented and non-supplemented medium and pure $\mathrm{S}$ oxidizing microorganisms for bioleaching of mobile phone printed circuit boards. Biosci Biotechnol Res Comm 12:425-434

Gorecka A, Poniatowska A, Macherzynski B, Wojewodka D, Wszelaka-Rylik ME (2019) Comparison of the effectiveness of biological and chemical leaching of copper, nickel and zinc from circuit boards. J Ecol Eng 20:62-69. https://doi.org/10.12911/22998993/112485

Hong Y, Valix (2014) Bioleaching of electronic waste using acidophilic sulfur oxidising bacteria. J Clean Prod 65:465-472

Ijadi Bajestani M, Mousavi S, Shojaosadati A (2014) Bioleaching of heavy metals from spent household batteries using Acidithiobacillus ferrooxidans: Statistical evaluation and optimization. Sep Purif Technol 132:309-316

Ilyas S, Lee J (2014) Bioleaching of metals from electronic scrap in a stirred tank reactor. Hydrometallurgy 149:50-62. https://doi.org/10.1016/j.hydro met.2014.07.004

Ilyas S, Anwar MA, Niazi SB, Afzal Ghauri M (2007) Bioleaching of metals from electronic scrap by moderately thermophilic acidophilic bacteria. Hydrometallurgy 88:180-188. https://doi.org/10.1016/j.hydromet.2007.04.007

Ilyas S, Ruan C, Bhatti HN, Ghauri MA, Anwar MA (2010) Column bioleaching of metals from electronic scrap. Hydrometallurgy 101:135-140

Ilyas S, Lee J-c, Chi R-a (2013) Bioleaching of metals from electronic scrap and its potential for commercial exploitation. Hydrometallurgy 131-132:138-143

Jadhav U, Sua C, Hocheng H (2016) Leaching of metals from printed circuit board powder by an Aspergillus niger culture supernatant and hydrogen peroxide. RSC Adv 6:43442-43452

Jung M, Yoo K, Alorro RD (2017) Dismantling of electric and electronic components from waste printed circuit boards by hydrochloric acid leaching with stannic ions. Mater Trans 58:1076-1080

Karwowska E, Andrzejewska D, Lebkowskaa M, Tabernackaa A, Wojtkowskab M, Telepkob A, Konarzewskab A (2014) Bioleaching of metals from printed circuit boards supported with surfactant-producing bacteria. J Hazard Mater 264:203-210
Kim Y, Seo H, Roh Y (2018) Metal recovery from the mobile phone waste by chemical and biological treatments. Minerals 8:8. https://doi.org/10.3390/ $\min 8010008$

Kumar A, Saini HS, Kumar S (2018) Enhancement of gold and silver recovery from discarded computer printed circuit boards by Pseudomonas balearica SAE1 using response surface methodology (RSM). 3 Biotech 8:100. https://doi.org/10.1007/s13205-018-1129-y

Lane DJ (1991) 16S/23S rRNA sequencing. In: Stackebrandt E, Goodfellow M (eds) Nucleic acid techniques in bacterial systematics. Wiley, Chichester, pp 115-175

Latha S, Vinothini G, Dhanasekaran D (2015) Chromium [Cr(VI)] biosorption property of the newly isolated actinobacterial probiont Streptomyces werraensis LD22. 3 Biotech. 5:423-432

Li J, Liang C, Ma C (2015) Bioleaching of gold from waste printed circuit boards by Chromobacterium violaceum. J Mater Cycles Waste Manag 17(3):529539. https://doi.org/10.1007/s10163-014-0276-4

Lin Y, Juan M, Huang H, Tsai H, Lin PH (2010) Influence of sulfur concentration on bioleaching of heavy metals from industrial waste sludge. Water Environ Res 82:2219. https://doi.org/10.2175/106143010X12609736966720

Lin Y, Wang X, Wang B, Mohamad O, Wei G (2012) Bioaccumulation characterization of zinc and cadmium by Streptomyces zinciresistens, a novel actinomycete. Ecotoxicol Environ Saf 77:7-17

Liu R, Lia J, Gea Z (2016) Review on Chromobacterium violaceum for gold bioleaching from e-waste. Procedia Environ Sci 31:947-953

Long J, Gao X, Su M, Li H, Chen D, Zhou S (2018) Performance and mechanism of biosorption of nickel(II) from aqueous solution by non-living Streptomyces roseorubens SY. Coll Surf A Physicochem Eng Asp 548:125-133

Madden AA, Grassetti A, Soriano JA, Starks PT (2013) Actinomycetes with antimicrobial activity isolated from paper wasp (Hymenoptera:Vespidae:P olistinae) nests. Environ Entomol 42:703-710

Madrigal-Arias J, Argumedo-Delira R, Alarcon A, Alarcon A, MendozaLopez, Barradas OG, Cruz-Sanchez O, Ferrera-Cerrato R, Jimenez-Fernandez M (2015) Bioleaching of gold, copper and nickel from waste cellular phone PCBs and computer goldfinger motherboards by two Aspergillus niger strains. Braz J Microbiol 46:707-713

Meng L, Wang Z, Zhong YW, Guo L, Gao JT, Chen KY, Cheng HJ, Guo ZC (2017) Supergravity separation for recovering metals from waste printed circuit boards. Chem Eng J 326:540-550

Mrazikova A, Marcincakova R, Kadukova J, Velgosova O (2013) Influence of bacterial culture to copper bioleaching from printed circuit boards. J Polish Min Eng Soc 5:59-62

Mrazikova A, Marcincakova R, Kadukova J, Velgosova O (2014) Nickel recovery from printed circuit boards using acidophilic bacteria. J Polish Min Eng Soc 1:51-54

Mrazikova A, Marcincakova R, Kadukova J, Velgosova O, Balintova M (2015) Influence of used bacterial culture on zinc and aluminium bioleaching from printed circuit boards. Nova Biotechnol Chimica 14:45-51

Mrazikova A, Kadukova J, Marcincakova R, Velgosova O, Willner J, Fornalczyk A, Saternus M (2016) The effect of specific conditions on $\mathrm{Cu}, \mathrm{Ni}, \mathrm{Zn}$ and $\mathrm{Al}$ recovery from PCBS waste using acidophilic bacterial strains. Arch Metall Mater 61:261-264

Narayanasamy M, Dhanasekaran D, Vinothini G, Thajuddin N (2018) Extraction and recovery of precious metals from electronic waste printed circuit boards by bioleaching acidophilic fungi. Int J Environ Sci Technol 15:119-132

Natarajan G, Ting YP (2014) Pretreatment of e-waste and mutation of alkalitolerant cyanogenic bacteria promote gold biorecovery. Bioresour Technol 152:80-85. https://doi.org/10.1016/j.biortech.2013.10.108

Oguchi M, Sakanakura H, Terazono A, Takigami H (2012) Fate of metals contained in waste electrical and electronic equipment in a municipal waste treatment process. Waste Manag 32:96-103. https://doi.org/10.1016/j. wasman.2011.09.012

Ojuederie OB, Babalola OO (2017) Microbial and plant-assisted bioremediation of heavy metal polluted environments: a review. Int J Environ Res Public Health 14:1504-1511

Pant D, Joshi D, Upreti MK, Kotnala RK (2012) Chemical and biological extraction of metals present in E waste: a hybrid technology. Waste Manage 32:979-990

Polti M, Aparicio JD, Benimeli CS, Amoroso MJ (2014) Simultaneous bioremediation of $\mathrm{Cr}(\mathrm{VI})$ and lindane in soil by actinobacteria. Int Biodeterior Biodegrad 88:48-55 
Pradeepa R, Senthilkumar P, Kavitha KK (2017) Review on microbial remediation of heavy metals from E-waste. Inter J Agric Life Sci 3:123-130

Pradhan J, Sudhir K (2012) Metals bioleaching from electronic waste by Chromobacterium violaceum and Pseudomonads sp. Waste Manag Res 1:1-9. https://doi.org/10.1177/0734242X12437565

Priya A, Hait S (2017) Comparative assessment of metallurgical recovery of metals from electronic waste with special emphasis on bioleaching. Environ Sci Pollut Res Int 24:6989-7008

Radhakrishnan M, Sakthivel M, Pazhanimurugan R, Balagurunathan R (2013) Antibacterial substance from Actinomycete strain TA4 isolated from Western Ghats, India. Indian J Appl Microbiol 16:9-16

Radhakrishnan M, Pazhanimurugan R, Gopikrishnan V, Balagurunathan R, Vanajakumar (2014) Streptomyces sp D25 isolated from Thar Desert soil, Rajasthan producing pigmented antituberculosis compound only in solid culture. J Pure App Micr 8:333-337

Rodrigues M, Leao V, Gomes O, Lambert F, Bastin D, Gaydardzhiev S (2015) Copper extraction from coarsely ground printed circuit boards using moderate thermophilic bacteria in a rotating-drum reactor. Waste Manag 41:148-158

Ruan J, Zhu X, Qian Y, Hu Y (2014) A new strain for recovering precious metals from waste printed circuit boards. Waste Manag 34:901-907

Saitou N, Nei M (1987) The neighbor-joining method: a new method for reconstructing phylogenetic trees. Mol Biol Evol 4:406-425

Shah B, Devayani R, Shailesh R (2014) Chemical and biological processes for multi-metal extraction from waste printed circuit boards of computers and mobile phones. Waste Manag Res 32:1134-1141

Shirling EB, Gottileb D (1966) Methods for characterization of Streptomyces species. Int J Syst Bact 16:313-340

Sun Z, Cao H, Xiao Y, Sietsma J, Jin W, Agterhuis H, Yang Y (2017) Toward sustainability for recovery of critical metals from electronic waste: the hydrochemistry processes. ACS Sustain Chem Eng 5:21-40. https://doi. org/10.1021/acssuschemeng.6b00841

Usha B, Ashok KS, Sharma S (2017) Metal extraction from the discarded printed circuit board by leaching. Int J Chem Stud 5:614-616

Vestola EA, Kuusenaho MK, Narhi N, Tuovinen OH, Puhakka JA, Plumb JJ, Kaksonen AH (2010) Acid bioleaching of solid waste materials from copper, steel and recycling industries. Hydrometallurgy 103:74-79

Wang J, Bai J, Xu J, Liang B (2009) Bioleaching of metals from printed wire boards by Acidithiobacillus ferrooxidans and Acidithiobacillus thiooxidans and their mixture. J Hazard Mater 172:1100-1105. https://doi. org/10.1016/j.jhazmat.2009.07.102

Wang Q, He AM, Gao B (2011) Increased levels of lead in the blood and frequencies of lymphocy tic micro-nucleated binucleated cells among workers from an electronic-waste recycling site. J Environ Sci Health Tox Hazard Subst Environ Eng 254:669-676

Weihua G, Bai J, Dai J, Zhang C, Yuan W, Wang J, Wang P (2014) Characterization of extreme acidophile bacteria (Acidithiobacillus ferrooxidans) bioleaching copper from flexible PCB by ICP-AES. J Spectroscopy. https:// doi.org/10.1155/2014/269351

Willner J (2012) Leaching of selected heavy metals from electronic waste in the presence of the Acidithiobacillus ferrooxidans bacteria. J Ach Mater Manuf Eng 55:860-863

Willner J, Kadukova J, Fornalczyk A, Saternus M (2015) Biohydrometallurgical process for metal recovery from electronic waste. Int J Appl Res 54:255-259

Wu W, Liu X, Zhang X, Zhu M, Tan W (2018) Bioleaching of copper from waste printed circuit boards by bacteria-free cultural supernatant of iron-sulfuroxidizing bacteria. Bioresour Bioprocess 5:10. https://doi.org/10.1186/ s40643-018-0196-6

Xia MC, Bao P, Liu AJ, Zhang SS, Peng TJ, Shen L, Yu RL, Wu XL, Li JK, Liu YD, Chen M, Qiu GZ, Zeng WM (2018) Isolation and identification of Penicillium chrysogenum strain Y5 and its copper extraction characterization from waste printed circuit boards. J Biosci Bioeng 126:78-87

Yamane HL, Moraes VT, Espinosa DCR, Tenor Rio JAS (2011) Recycling of WEEE: characterization of spent printed circuit boards from mobile phones and computers. J Waste Manag 31:2553-2558

Yang T, Xu Z, Wen J, Yang L (2009) Factors influencing bioleaching copper from waste printed circuit boards by Acidithiobacillus ferrooxidans. Hydrometallurgy 97:29-32

Yanga Y, Chena S, Li S, Chena S, Chena H, Liub B (2014) Bioleaching waste printed circuit boards by Acidithiobacillus ferrooxidans and its kinetics aspect. J Biotechnol 173:24-30

Yazici EY, Deveci $\mathrm{H}$ (2013) Extraction of metals from waste printed circuit boards (WPCBs) in $\mathrm{H}_{2} \mathrm{SO}_{4}-\mathrm{CuSO}_{4}-\mathrm{NaCl}$ solutions. Hydrometallurgy 139:30-38

Zhao G, Wang Z, Dong MH, Rao K, Luo J, Wang D, Zha J, Huang S, Xu Y, Ma M (2008) PBBs, PBDEs, and PCBs levels in hair of residents around e-waste disassembly sites in Zhejiang Province, China, and their potential sources. Sci Total Environ 397:46-57

\section{Publisher's Note}

Springer Nature remains neutral with regard to jurisdictional claims in published maps and institutional affiliations.

\section{Submit your manuscript to a SpringerOpen ${ }^{\circ}$ journal and benefit from:}

- Convenient online submission

- Rigorous peer review

- Open access: articles freely available online

- High visibility within the field

- Retaining the copyright to your article

Submit your next manuscript at $\boldsymbol{\nabla}$ springeropen.com 